\title{
Performance of Polypropylene Fibre Reinforced Laterite Masonry Bricks
}

\author{
Nourou Mahaman Lawali Salaou ${ }^{1, *}$, Joseph Thuo ${ }^{2}$, Charles Kabubo ${ }^{3}$, \\ Zachary Abiero Gariy ${ }^{3}$
}

\author{
${ }^{1}$ Pan-African University Institute for Sciences, Technology and Innovation (PAUSTI), Kenya \\ ${ }^{2}$ Department of Building and Civil Engineering, Dedan Kimathi University of Technology, Kenya \\ ${ }^{3}$ Department of Building and Civil Engineering, Jomo Kenyatta University of Agriculture and Technology, Kenya
}

Received July 5, 2021; Revised September 13, 2021; Accepted October 17, 2021

\section{Cite This Paper in the following Citation Styles}

(a): [1] Nourou Mahaman Lawali Salaou, Joseph Thuo, Charles Kabubo, Zachary Abiero Gariy , "Performance of Polypropylene Fibre Reinforced Laterite Masonry Bricks," Civil Engineering and Architecture, Vol. 9, No. 7, pp. 2178-2186, 2021. DOI: 10.13189/cea.2021.090707.

(b): Nourou Mahaman Lawali Salaou, Joseph Thuo, Charles Kabubo, Zachary Abiero Gariy (2021). Performance of Polypropylene Fibre Reinforced Laterite Masonry Bricks. Civil Engineering and Architecture, 9(7), 2178-2186. DOI: 10.13189/cea.2021.090707.

Copyright $(2021$ by authors, all rights reserved. Authors agree that this article remains permanently open access under the terms of the Creative Commons Attribution License 4.0 International License

\begin{abstract}
Accessibility to energy-efficient, cost-effective, and environmentally friendly materials are among the critical challenges that the building industry faces. In addition to its high cost, concrete and cement blocks or structures production is one of the factors that cause climate change. Therefore, the building industry has to develop innovative materials that contribute to the reduction of the challenges above. Due to its availability worldwide and its environmentally friendly characteristics, earth materials appear suitable against climate change in the building industry. However, blocks produced from earth materials have low compressive and tensile strengths and low durability. Recently, many researchers focused on stabilising soil with cement, lime, fibres, Etc. Cement/lime

splitting tensile test, compression test and initial rate of water absorption test are presented in this paper. The results indicate that the compressive strength of reinforced bricks increased by $84 \%$, and the water absorption rate was reduced by $50 \%$ at $0.23 \%$ fibre content by weight of dry soil. These results show that polypropylene fibre can be an alternative reinforcement material to produce more durable earth blocks and bricks with improved compressive strength. It is recommended that one should mix dry laterite soil with fibre. Then add the optimum water content determined from the compaction test and mix until the mixture is homogenous before making blocks/bricks. Blocks/bricks made should be air-dried, avoiding exposition to sunlight.
\end{abstract} stabilisation is neither cost-effective nor energy-efficient, while natural fibres reinforcement faces durability challenges. In this study, a laterite soil was reinforced with polypropylene fibre, a type of waste plastic. The use of these plastic wastes contributes to reducing plastic worldwide and producing low-cost and environmentally friendly building materials. The main objective of this research work is to study the performance of polypropylene reinforced laterite bricks. A hair-like polypropylene fibre was mixed with air-dried laterite soil at $0,0.05,0.1,0.15$, $0.20,0.25,0.30$, and $0.4 \%$ fibre content by weight of dry soil. The blocks and bricks made were air-dried for 14 days and tested according to EN 772-1:2011 (E). The findings on the unconfined compressive strength test, indirect
Keywords Laterite Soil, Polypropylene Fibre, Earth Bricks

\section{Introduction}

Laterite soil is among the most used earth materials in the building industry. Houses built with laterite soil bricks have good thermal isolation and are cheaper and more environmentally friendly than concrete/cement [1]. Earth as a construction material lacks certain engineering properties. For example, earth bricks suffer from 
shrinkage, cracking, low strength, and low durability [2]. Many studies have focused on soil stabilisation or soil reinforcement using cement/lime, natural or synthetic fibres to improve soil performances. However, even though the cement/lime stabilisation reduces the emission of $\mathrm{CO}_{2}$ compared to concrete and fired clay blocks, it remains expensive, requires much energy and is not environmentally friendly compared to fibre reinforcement. In order to come up with alternative materials for low-cost constructions and more environmentally friendly, other researchers have focused on soil reinforcement with natural fibres. In general, natural fibres exhibit good mechanical and physical properties with desirable fibre aspect ratios. Because of their technical and economic advantages, natural fibres are among suitable reinforcing materials in the building industry [3]. But the main challenge with natural fibres remains the durability of the composite [4]-[6].

To produce more durable, low-cost alternative soil material and reduce plastic waste worldwide, researchers have recently studied the reinforcement of soil with synthetic fibres. Synthetic fibres are cheaper, more durable, stretchable; they have better waterproofing, stain resistance, and fire resistance than natural fibres [7]. According to Andal \& Juanzon [8], sustainable building materials should be energy-efficient, non-toxic and low-cost. The addition of nylon fibres to silty clay soil reduces the compaction energy and increases the peak and residual strength of the soil [9]. When used as fine sand soil reinforcement, Polyethylene Terephthalate (PET) fibres have shown an increase in the peak and ultimate strengths depending upon the fibre content. Three lengths of flat fibres $(3 \mathrm{~mm}, 6 \mathrm{~mm}$ and $12 \mathrm{~mm})$ and crimped fibres cut to $3 \mathrm{~mm}$ long were used [10]. The results have shown that the unconfined compressive strength value increased with fibre length or fibre content with flat fibres. A slight increase of unconfined compressive strength was observed in the case of crimped fibres. Menon \& Ravikumar [11] evaluated the effects of Polyethylene Terephthalate (PET) bottle fibres and Polypropylene sack fibres separately on the unconfined compressive strength of a clayey silt soil. They reported that an unconfined compressive strength of $0.61 \mathrm{MPa}$ was achieved at polypropylene fibre optimum content $(0.15 \%$ by dry weight of soil). In comparison, PET fibre reinforcement produced an unconfined compressive strength of $0.58 \mathrm{MPa}$ at the optimum fibre content $(0.20 \%$ by dry weight of soil). Kumar et al. [12]studied the performance of polypropylene fibre reinforced a mixture of soft clay and sand with fibre content ranging from $0.5 \%$ to $2 \%$. They reported increased compression strength of fibre reinforced soil with increasing fibre content and length. Abdullah et al. [13] reported that polypropylene fibre reinforcement increases the unconfined compressive strength of weak soil, and the optimum fibre content was $0.15 \%$ by weight of dry soil. Han et al. [14] studied the shear strength of polypropylene fibre reinforced clay with different fibre lengths. They reported that the cohesion of the fibre reinforced soil reached a peak with fibre lengths of 3,6 and $9 \mathrm{~mm}$ at $0.1,0.2$ and $0.3 \%$, respectively, and then dropped. In contrast, with a fibre length of $12 \mathrm{~mm}$, the cohesion of the soil keeps increasing with increased fibre content over all the percentages studied. Jalaei \& Jrade [15] reported an increase in compressive and flexural strengths of compressed stabilised earth bricks with increasing polypropylene fibre content and length and found the maximum strengths at $0.2 \%$ fibre content with $54 \mathrm{~mm}$ fibre. Selsiadevi \& Ramani Sujatha [16] reported increased compressive strength of polypropylene fibre reinforced soil bricks with increasing fibre content (ranging from 0 to $1 \%$ fibre content by weight of dry soil), with a fibre aspect ratio of 80 .

From the reviewed literature above, it can be seen that polypropylene fibre reinforced soil was studied by some researchers [4], [11]-[17]. However, the application of polypropylene fibre reinforcement on compressed earth bricks still needs to be investigated, particularly the durability of polypropylene fibre reinforced compressed earth blocks and bricks.

\section{Materials and Methods}

This section describes the materials and methods used during the current experiments.

\subsection{Materials}

Laterite soil, polypropylene fibre and potable water are the materials that were used in this study. Particle size distribution test, maximum dry density test, moisture content test, Atterberg Limit Test, unconfined compression test and chemical analysis of soil were used to characterize the laterite and fibre reinforced laterite soil on the one hand. On the other hand, indirect tensile splitting strength test, compressive strength test and water absorption test are used to determine the performance of laterite and fibre reinforced laterite blocks and bricks.

\subsubsection{Laterite}

For the purpose of this research, laterite material which is abundant in most parts of Kenya was borrowed from a laterite soil quarry JKUAT Juja, Kenya.

\subsubsection{Polypropylene Fibres}

Polypropylene fibre was procured from Masters Builders company in Nairobi Kenya. Figure 1 below shows an image of polypropylene fibre as received.

\subsubsection{Fibre Aspect Ratio}

The fibre aspect ratio is a convenient parameter that is usually used to describe the fibres. It is calculated by dividing fibre length (l) by its diameter (d). The aspect 
ratio of the fibre is an essential factor that influences the composite's properties and behaviour [2]-[4].

A fibre aspect ratio of $231(6 \mathrm{~mm}$ in length and 0.026 $\mathrm{mm}$ in diameter) was used in this research. This because studies have shown that the lower is the fibre aspect ratio better is the compressive strength of the composite [4], [18], [19].
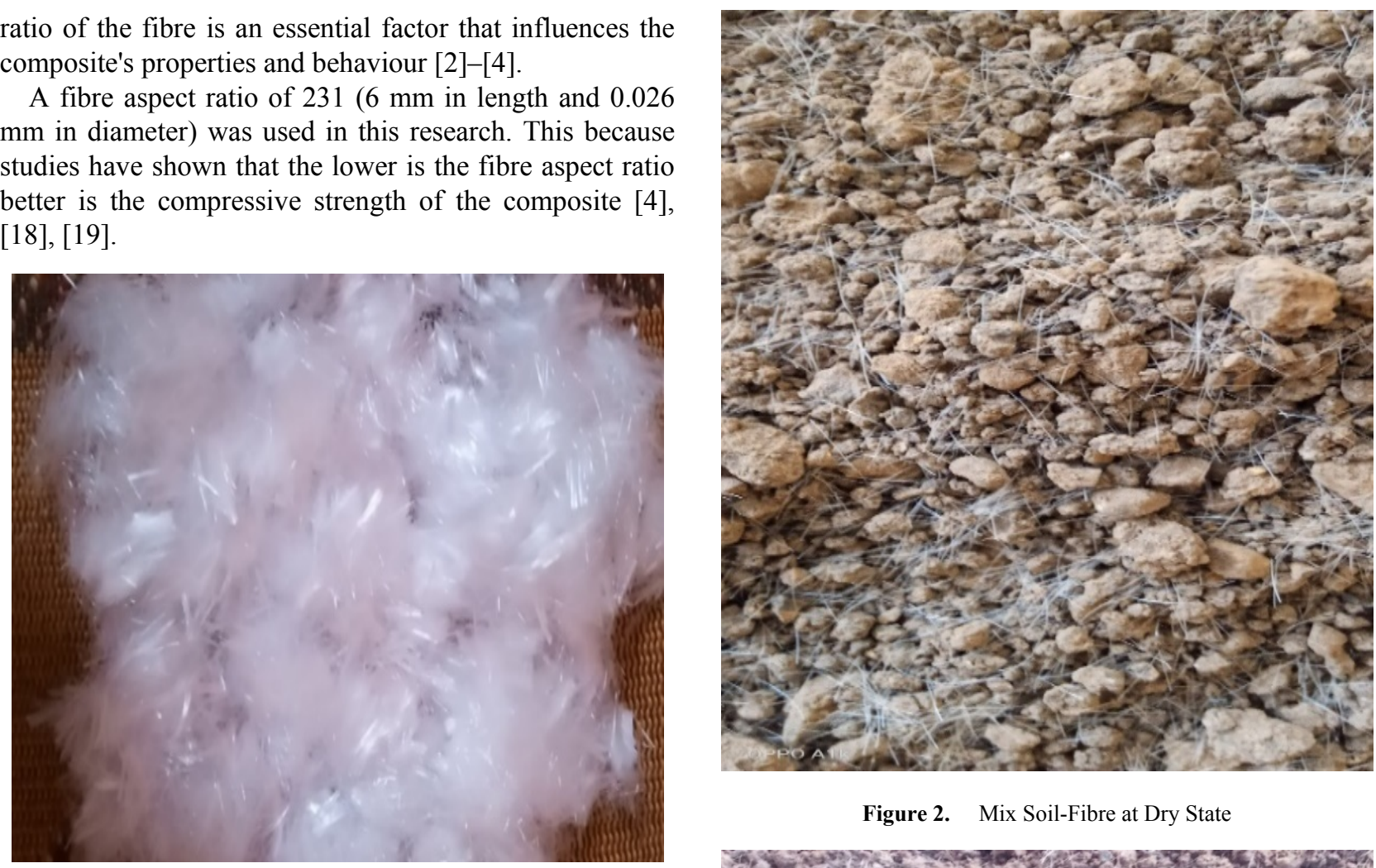

Figure 2. Mix Soil-Fibre at Dry State

Figure 1. Polypropylene Fibre

\subsection{Methods}

\subsubsection{Preparation of Blocks/Bricks Mix}

The soil and fibre were thoroughly mixed manually at a dry state until a homogenous mix was obtained. The optimum moisture content was then added, and blocks were made. Bricks of 290x140x120 mm in length, width and height were made with a manual press machine, while cylinders of $127 \mathrm{~mm}$ high and $100 \mathrm{~mm}$ in diameter were made using an automatic compaction machine at the dry density of the bricks. Figures 2 and 3 show the dry and wet mixes of soil-fibre composite, respectively. While Figure 4 shows manual press.

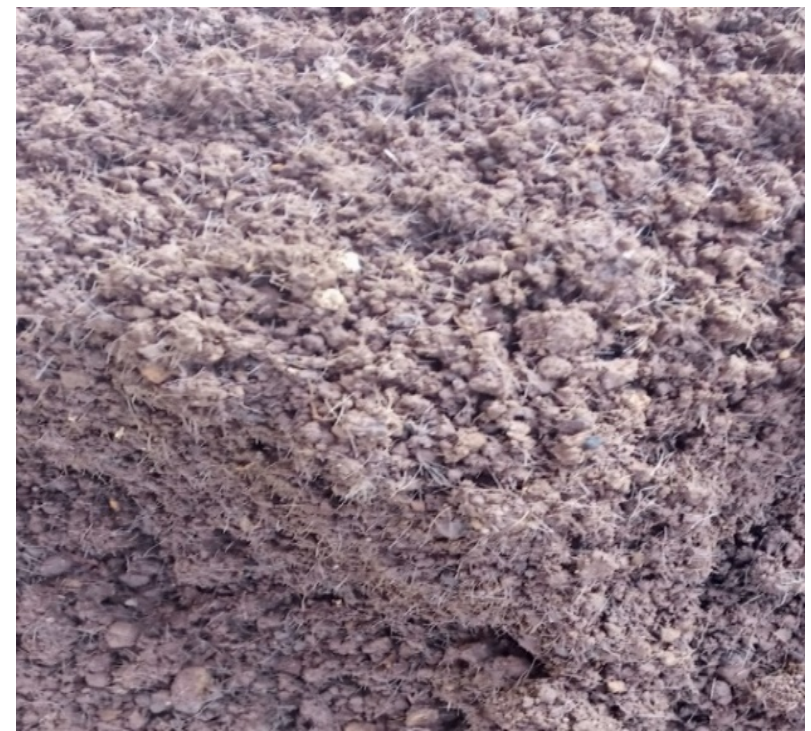

Figure 3. Fibre-Soil Wet Mix 


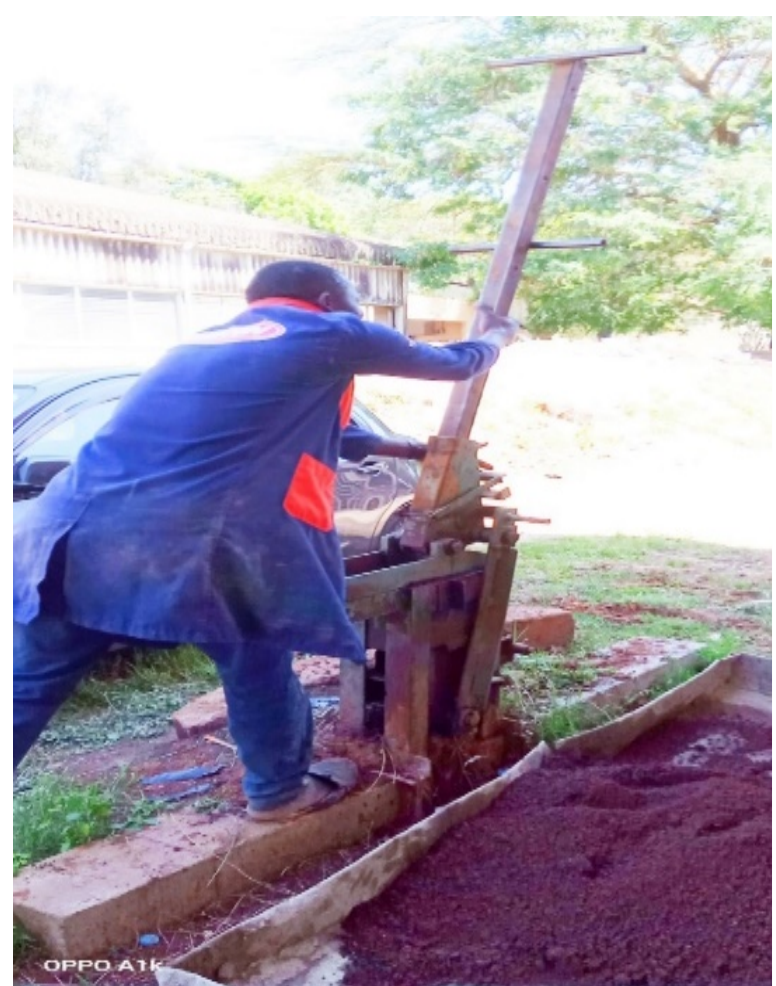

Figure 4. Manual press

\subsubsection{Curing of Blocks/Bricks}

All the blocks made in this study were air dried following the procedure described in EN 772-1:2011 (E)a). Figure 5 shows bricks under air-drying.

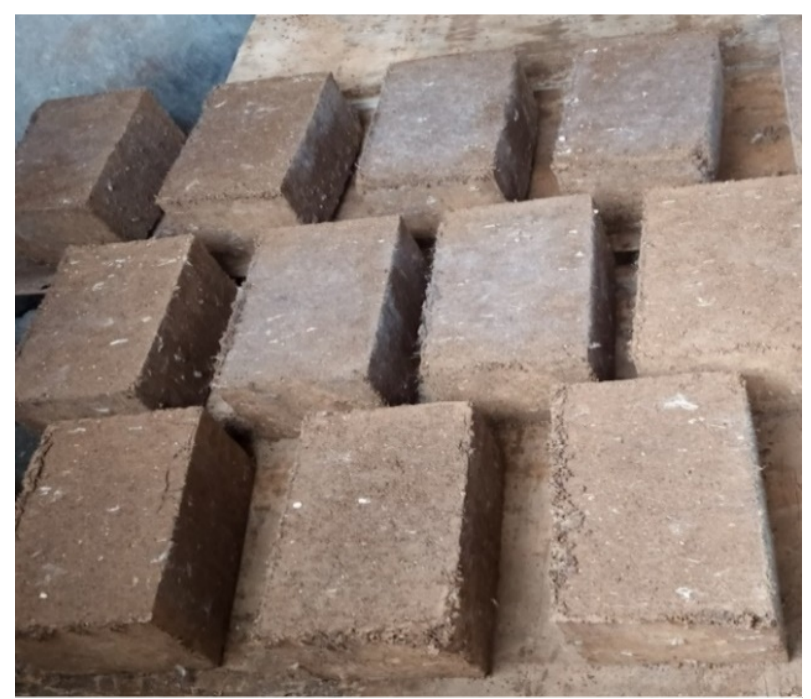

Figure 5. Bricks under curing

\subsubsection{Compression Test}

The compressive strength is the most critical parameter used to characterize the earth bricks; load bearing and non-load bearing bricks are differentiated based on the compressive strength. In this research, the compressive strength test was carried out on bricks after 14 days of air drying or when a constant dry mass was reached between two subsequent measurements with not less than a $24 \mathrm{~h}$ interval following BS EN 772-1 (2011). A compressive load was applied at a rate of $0.1 \mathrm{~N} / \mathrm{mm}^{2} / \mathrm{s}$ until the brick failure, after which the maximum compressive load and maximum compressive strength of the bricks were directly read on a screen associated with the compression machine.

\subsubsection{Indirect Tensile Splitting Strength Test}

The splitting tensile strength test was used to assess the tensile strength of brittle materials like mortar because a direct tensile test cannot be performed on such materials. In order to perform this test, cylinders of soil and soil-fibre mixed were made using an automatic compaction machine, and the number of blows to be applied were determined using the dry density of bricks. The tensile splitting test was carried out on cylinders following BS EN 12390-6 (2009) (British Standards Institution BSI, 2009) after 14 days of air drying. A load was applied continuously at a steady rate of $0.05 \mathrm{~N} /$ $\mathrm{mm} 2 / \mathrm{s}$ up to the failure of the cylinder, and the maximum value of the splitting tensile strength was recorded. Figure 6 shows an ongoing splitting tensile test.

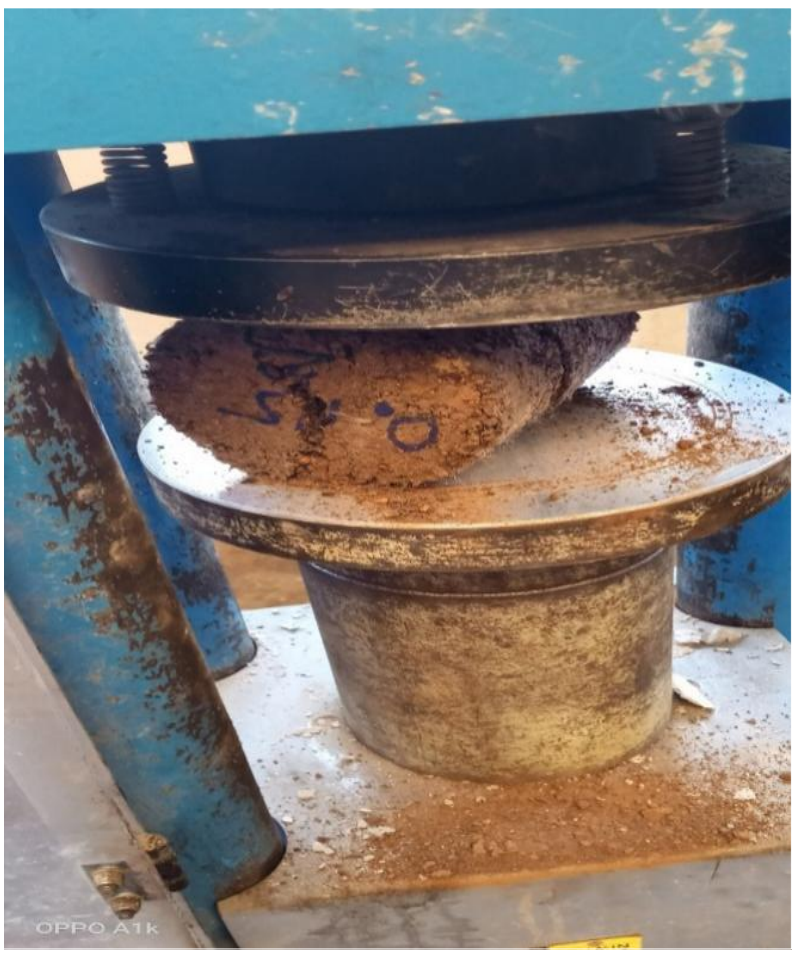

Figure 6. Splitting tensile test

\subsubsection{Unconfined Compression Test (BS 1377: Part 7:1990:7.2 and ASTM D 2166)}

The unconfined compression test is used to estimate the undrained shear strength of soils containing gravel size particles, stiff fissured clays and non-homogeneous soils. Axial compression load was applied to a cylindrical soil 
specimen at a constant deformation rate (the strain-controlled procedure). The ASTM controlled strain procedure is similar, and that standard also includes a procedure using controlled stress, in which the axial force is increased incrementally at regular intervals of time [5][7]. After the preparation, the specimen was placed in the unconfined compression test apparatus or autographic apparatus. The axial compression load was then applied, and readings were recorded until the failure of the specimen. After the specimen failure, the system was unloaded.

\subsubsection{Initial Rate of Water Absorption}

The initial water absorption rate is one of the parameters used to evaluate the durability of earth bricks. In this study, the initial rate of water absorption test was conducted as per the EN 771-1:2003 (E). The bricks were air-dried, weighed and placed in an oven for 24 hours. After that, the bricks were left to cool for a minimum period of one hour, then weighed, and the bed face was immersed in cold water at a maximum of $5 \mathrm{~mm}$ depth for one minute to absorb water. They were then taken out of the water, wiped and weighed again. The initial rate of water absorption is given by the difference of the masses (wet mass - dry mass) over the area for one minute.

\section{Results and Discussion}

\subsection{Laterite Soil Characteristics}

The soil characterization tests were conducted as per British standards (BS 1377: Part 2\&3: 1990) and European standards (BS EN 1997-2:2007). The results of soil characterization are summarized in the Tables 1 and 2 below.

Table 1. Physical Properties of the Soil

\begin{tabular}{|c|c|}
\hline Property & value \\
\hline Specific gravity & 2.67 \\
\hline Atterberg limits & \\
Liquid limit (\%) & 41.74 \\
Plastic limit (\%) & 22.73 \\
Plasticity index & 19.01 \\
\hline Particle size distribution & \\
Gravel (\%) & 55 \\
Sand (\%) & 15 \\
Silt (\%) & 12 \\
Clay (\%) & 18 \\
\hline Soil classification USCS & $\mathrm{SC}$ \\
\hline Compaction characteristic (standard proctor) & \\
Maximum dry unit weight $\left(\mathrm{kg} / \mathrm{m}^{3}\right)$ & 1882 \\
Optimum moisture content $(\%)$ & 14.88 \\
\hline
\end{tabular}

Amadi [20] reported an MDD of $1.78 \mathrm{~g} / \mathrm{cm}^{3}$ with an OPC of $17.57 \%$ and a specific gravity of 2.64 for a laterite soil classified as CL (low plasticity clay). Fajobi et al. [21] found a range of MDDs values from 1720 to $1880 \mathrm{~kg} / \mathrm{m}^{3}$ with OPCs varying from 11 to $15 \%$ and specific gravities from 2.62 to 2.70 for laterites from different locations, all classified as SC. For Ogunsanwo [22], the specific gravity of laterite soils varies from 2.73 to 2.78 . According to García et al. [23], based on USCS, a soil with a liquid limit less than 50 is a low plasticity soil. Therefore, the soil used in this study is a low plasticity soil. From the literature reviewed, it can be said that the characteristics of the soil used in this study are in the range of laterite soils.

Table 2. Chemical Properties of the Soil by XRF

\begin{tabular}{|c|c|}
\hline Element & Proportion (\%) \\
\hline Iron as $\mathrm{Fe}_{2} \mathrm{O}_{3}$ & 46.77 \\
\hline Silica as $\mathrm{SiO}_{2}$ & 33.43 \\
\hline Aluminium as $\mathrm{Al}_{2} \mathrm{O}_{3}$ & 6.49 \\
\hline Manganese as $\mathrm{MnO}$ & 4.38 \\
\hline Titanium as $\mathrm{TiO}$ & 3.21 \\
\hline Calcium as $\mathrm{CaO}$ & 1.52 \\
\hline Potassium as $\mathrm{K}_{2} \mathrm{O}$ & 1.09 \\
\hline Phosphorus as $\mathrm{P}_{2} \mathrm{O}_{5}$ & 1.05 \\
\hline Sulphur as $\mathrm{S}$ & 0.75 \\
\hline Barium as $\mathrm{Ba}$ & 0.51 \\
\hline Zirconium as $\mathrm{Zr}$ & 0.28 \\
\hline Zinc as $\mathrm{Zn}$ & 0.26 \\
\hline Niobium as $\mathrm{Nb}$ & 0.08 \\
\hline Yttrium as $\mathrm{Y}$ & 0.03 \\
\hline Nickel as $\mathrm{Ni}$ & 0.02 \\
\hline Lead $\mathrm{Pb}$ & 0.02 \\
\hline Rubidium as $\mathrm{Rb}$ & 0.02 \\
\hline & \\
\hline & \\
\hline & \\
\hline
\end{tabular}

Ratio:

$$
\mathrm{SiO} / \mathrm{AlO}_{3}=\frac{33.43}{46.77}=0.715
$$

Martin [24] and Achampong et al. [25] qualified soil with the silica-alumina ratio $(\mathrm{SiO} / \mathrm{AlO} 3)$ less than 1.33 as true laterites. Therefore, the soil used in this research is laterite soil.

\subsection{Properties of Polypropylene Fibre USED in This Study}

The current research studied the effects of randomly distributed polypropylene fibre on laterite soil bricks. The engineering properties of fibre used in the current study are summarized in Table 3.

As shown in Table 1, the polypropylene fibre used in this research has low density, good fire resistance and very good tensile strength. These properties, plus anti-ageing resistance and non-biodegradability, confer very good flexibility and durability characteristics to the fibre. The latter is very important in a reinforcing material to produce a more composite. 
Table 3. Engineering Properties of Polypropylene Fibres

\begin{tabular}{|c|c|}
\hline Property & Value \\
\hline Material & $100 \%$ Polypropylene \\
\hline Fibre type & Bunchy monofilaments \\
\hline Density & $0.91 \mathrm{~g} / \mathrm{cm}^{3}$ \\
\hline Acid and alkali & High \\
\hline melting point & about $160^{\circ} \mathrm{c}$ \\
\hline conductivity for heat & very low \\
\hline containing moisture & $<0.1$ \\
\hline elongation at break & 30 \\
\hline length & $6 \mathrm{~mm}$ \\
\hline tensile strength & $>400 \mathrm{MPa}$ \\
\hline young modulus & $>3.5 \mathrm{GPa}$ \\
\hline fibre diameter & $0.026 \mathrm{~mm}$ \\
\hline burning point & $580^{\circ} \mathrm{c}$ \\
\hline safety & Non-toxic material \\
\hline ageing resistance & Anti-ageing resistance \\
\hline
\end{tabular}

$<$ Source: Masters Builders - polypropylene fibre supplier in Nairobi, Kenya $>$

\subsection{Unconfined Compressive Strength}

The unconfined compressive strength test results are presented in Figure 7.

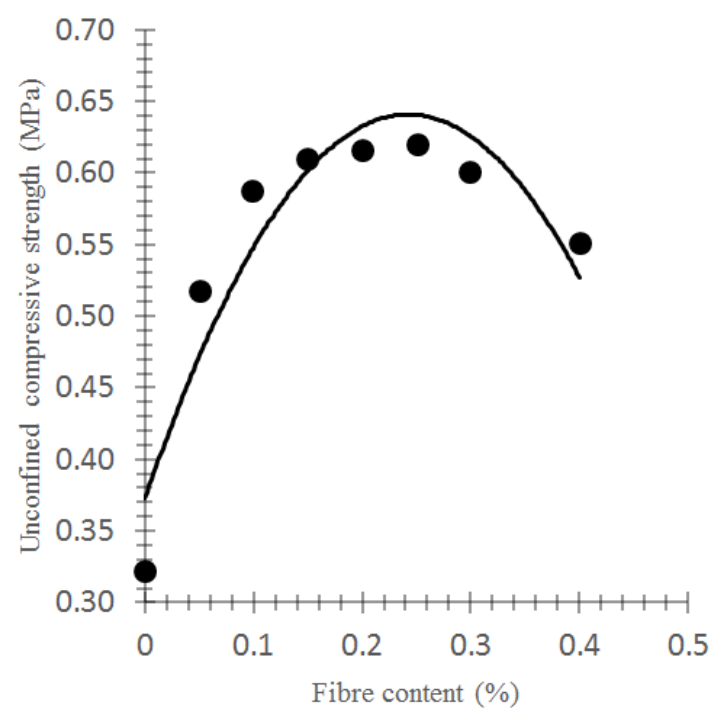

Figure 7. Unconfined Compressive vs Fibre Content

These results show that polypropylene fibre increases the unconfined compressive strength of laterite soil up to a certain point and decreases slowly. The optimum fibre content reached at $0.25 \%$ fibre content of the dry weight of the soil. At this point, the composite's unconfined compressive strength value was twice that of the plain soil. The inclusion of polypropylene fibre changed the soil failure behaviour from brittle to ductile. That means fibres bridged the development of cracks within the composite
[26]. From the above curve, it can be said that the increase in fibre content increases the number of fibres in the sample, which increases the contact between soil particles and fibre. Therefore, the volume of voids is reduced, and the strength of the composite increased [27]. When the fibre content is greater than $0.25 \%$, small balls of fibre are formed in the soil-fibre matrix, which can create voids and weakness planes after drying, and that may be why the unconfined compressive strength drops.

These results are similar to those reported by Menon \& Ravikumar [11], who evaluated the performances of polyethene and polypropylene fibres on a laterite soil with a different fibre aspect ratio $(15 \mathrm{~mm}$ length and $2 \mathrm{~mm}$ width). Han [14] studied the shear strength of polypropylene fibre reinforced clay varying polypropylene fibre length. They reported that with polypropylene fibre 3, 6, 9 and $12 \mathrm{~mm}$, the cohesion of the composite increases up to an optimum point and then decreases. A similar trend was also reported by Al-Neami [28] with polypropylene fibre reinforced clay $(12 \mathrm{~mm}$ in length with a mean diameter of $0.034 \mathrm{~mm}$ ). The trend found in this study is similar to that reported by Taha et al. [29] when studying the influence of polypropylene fibre (PPF) reinforcement on the mechanical properties of clay soil. Dave et al. [30] reinforced a cohesive soil with polypropylene fibre 10,20 and $30 \mathrm{~mm}$ lengths and 0.05 $\mathrm{mm}$ diameter. They reported that the unconfined compressive strength increases up to optimum fibre content with polypropylene fibre reinforcement and then decreases. But the results found in this study are not similar to those reported by [31], [32], who found that the unconfined compressive strength increases with increasing fibre content.

\subsection{Splitting Tensile Strength}

The splitting tensile strength test results are presented on Figure 8.

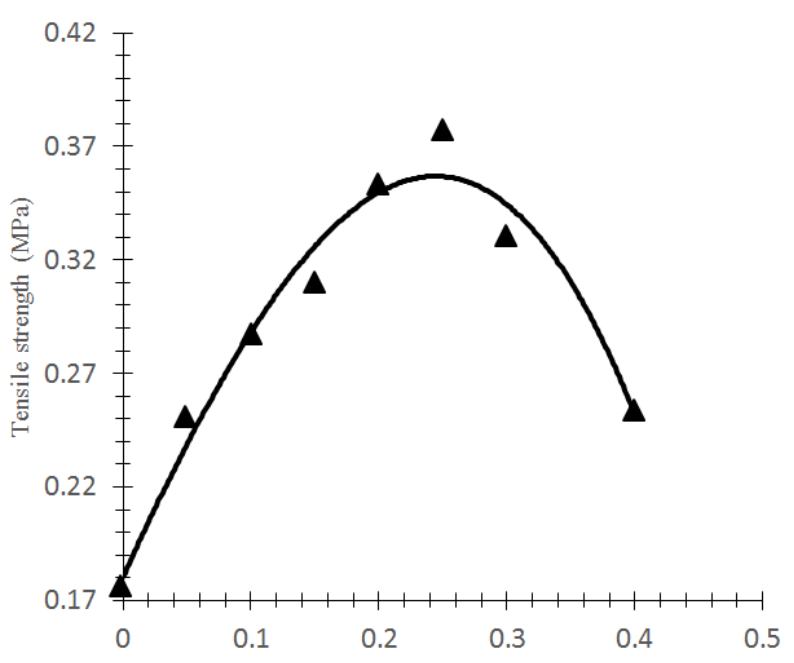

Figure 8. Splitting Tensile Strength vs Fibre Content 
The above curve shows that monofilament fibre increases the tensile strength of laterite soil until an optimum content and decreases with the further inclusion of fibre. The best effect was obtained at $0.25 \%$ fibre content to the dry weight of the soil, corresponding to an increase of $94 \%$ of neat soil. Based on these results, it can be said that monofilament fibres act as a bridge in a loaded composite to prevent the extension of tensile cracks and therefore prevent the sample of brittle or catastrophic failure. The findings also suggested that the fibres increase the bonding of soil particles surrounding the individual fibres and aid to transfer and distribute the load between them uniformly, thus delaying the failure of the composite and increasing the tensile strength of reinforced soil [15][28][33].

It can be seen from the curve that the tensile strength decreases when the fibre content exceeds high $(>0.25 \%)$. This result may be due to the formation of fibre balls inside the composite matrix, which after curing, can create voids and plans of weakness in the matrix, resulting in the decrease of reinforced block tensile strength. Results found in this research are similar to those reported by Chuitou [4], who stated that the decrease in tensile strength of the composite was may be due to the formation of fibre balls in the composite at the high fibre content. Jalaei \& Jrade [15] reported similar results on compressed stabilized earth bricks reinforced with polypropylene fibre and concluded that the inclusion of fibre prevents catastrophic failure and improves the post-initial crack performance of the sample. Results found here (Figure 8) are at variance with Selsiadevi \& Ramani [16] ones. They reported that the tensile strength of polypropylene fibre (12 mm length and $0.15 \mathrm{~mm}$ diameter) reinforced laterite soil bricks increases with the increase in fibre content, and the investigation was conducted up to $1 \%$ fibre content by the dry weight of the soil. The results reported in this study are also not in line with those obtained by Malekzadeh \& Bilsel [34], who found that the tensile strength of a cohesive soil reinforced with polypropylene fibre increased with increased fibre content.

\subsection{Compression Strength of the Bricks}

Figure 9 presents the results of the compression test on the soil and soil-fibre bricks.

From the compression test curves in Figure 6, it can be seen that polypropylene reinforcement improves the compression strength of compressed earth bricks. The best effect was obtained with $0.23 \%$ fibre content, and the corresponding value is approximately $7 \mathrm{MPa}$. With this value, the compressive of the plain soil bricks was improved by about $84 \%$. According to BS3921:1985, the minimum required compressive strength for load-bearing earth bricks is $5 \mathrm{MPa}$. The Australian Standard requires a minimum compressive strength of $1.15 \mathrm{~N} / \mathrm{mm} 2$, and the ASTM International E2392/E2392M-10e1 (2010) indicates a value of $2.068 \mathrm{~N} / \mathrm{mm} 2$ for non-load bearing blocks [5]. With regard to BS3921:1985, the polypropylene fibre reinforced bricks made in this study can be used as load-bearing bricks at the optimum fibre content.

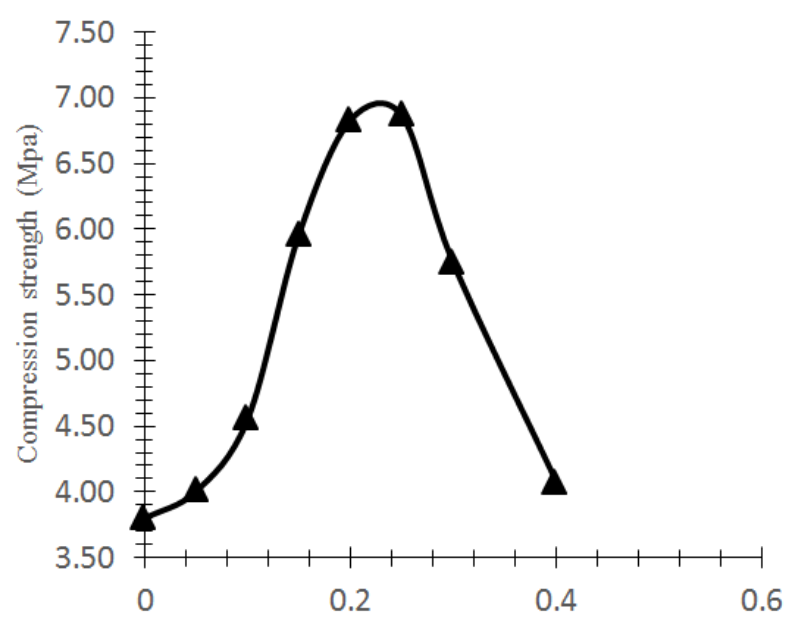

Figure 9. Compression Strength vs Fibre Content

The results found in this study (Figure 9) show that monofilament fibre, when mixed with soil, fill up the voids between the soil particles, and with the increase of fibre content, the contact between soil particles and individual fibres increases, which results in an increase of soil-fibre composite compressive strength up to the optimum fibre content. The increase in compressive strength of polypropylene fibre reinforced concrete specimens may be attributed to the polypropylene fibre acting as a bonding material between the surrounding particles or to the geometric shape and interface of the fibre [15]. Selsiadevi \& Ramani Sujatha [16] attributed the increase in strength to the frictional resistance developed between the fibre and the soil matrix. It is also important to note that the failure mode in every test with monofilament polypropylene fibre was ductile, while with unreinforced soil, the failure was brittle.

Results found in this study are at variance with those reported by [16].

\subsection{Initial Rate of Water Absorption}

The initial water absorption rate test was carried out on bricks after air and oven drying. The test results are shown in Figure 10.

The results in Figure 10 show that the initial water absorption rate decreases with increasing fibre content and tends to be constant from certain fibre content. These findings show that when mixed with soil, monofilament fibre fills up the voids in the composite matrix, allows the composite to develop a better water resistance compared to the unreinforced soil one and consequently improves the durability of the bricks. Ali [35] stipulated that the good value of the initial rate of water absorption is $0.25-2$ 
$\mathrm{kg} /(\mathrm{m} 2 \mathrm{xmin})$ in the case of earth bricks without a binder (cement, lime, etc.), while ASTM C67 requires a range from $0.39-1.18 \mathrm{~kg} /(\mathrm{m} 2 \mathrm{xmin})$, this means that the results found with reinforced soil in this study are largely in line with the standards.

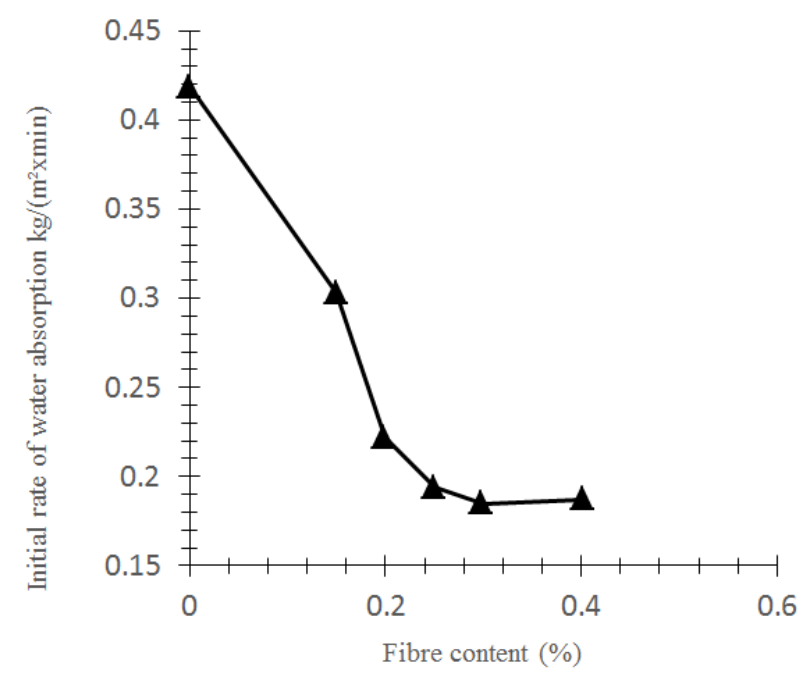

Figure 10. Initial rate of water absorption vs fibre content

\section{Conclusions}

This study was conducted to investigate the performance of polypropylene fibre reinforced bricks to improve the raw soil bricks performance. This paper reported the results with $6 \mathrm{~mm}$ fibre on unconfined compressive strength on the soil and the reinforced soil, the indirect splitting tensile strength, the compressive strength and the initial water absorption rate of the bricks. The study revealed that the inclusion of monofilament fibre fills effectively up the voids between the soil particles in the composite, and the following conclusions can be drawn:

1. With the inclusion of fibre, the unconfined compressive strength increased to twice that of neat soil at the optimum point to a fibre content of $0.25 \%$.

2. The inclusion of fibre increases the indirect splitting tensile of the composite and the best effect was obtained at $0.25 \%$ fibre content by the dry weight of the soil corresponding to an increase of $62 \%$ of that of neat soil. Further addition of fibre results in decreased splitting tensile strength.

3. The compressive strength of the composite bricks was improved and the best effect was obtained with an optimum fibre content of $0.23 \%$ fibre content by the dry weight of the soil corresponding to an increase of $84 \%$ compare to the unreinforced soil bricks strength.

4. The inclusion of fibre improves the initial rate of water absorption. A 50\% reduction of water absorption rate was achieved as compared to the bricks at a fibre content of $0.23 \%$.
5. The addition of fibre changes the specimen's failure behaviour from brittle with neat soil to ductile with reinforced soil and therefore prevents the post initial crack development.

\section{Recommendations}

It is recommended that one should mix dry laterite soil with fibre. Then add the optimum water content determined from the compaction test and mix until the mixture is homogenous before making blocks/bricks. Blocks/bricks made should be air-dried, avoiding exposition to sunlight. Further investigations with a longer length and higher fibre content on clay and laterite stabilized earth bricks.

\section{REFERENCES}

[1] A. H. Abdullah, S. Nagapan, A. Antonyova, K. Rasiah, R. Yunus, and S. Sohu, "Comparison of Strength between Laterite Soil and Clay Compressed Stabilized Earth Bricks (CSEBs)," MATEC Web Conf., vol. 103, 2017, doi: 10.1051/matecconf/201710301029.

[2] H. Danso, D. B. Martinson, M. Ali, and J. B. Williams, "Physical, mechanical and durability properties of soil building blocks reinforced with natural fibres," Constr. Build. Mater., vol. 101, pp. 797-809, 2015, doi: 10.1016/j.conbuildmat.2015.10.069.

[3] B. Buitrago, F. Jaramillo, and M. Gómez, "Some Properties of Natural Fibers (Sisal, Pineapple, and Banana) in Comparison to Man-Made Technical Fibers (Aramide, Glass, Carbon)," J. Nat. Fibers, vol. 12, no. 4, pp. 357-367, 2015, doi: 10.1080/15440478.2014.929555.

[4] I. A. Chuitou, "Structural and hydraulic performance of polypropylene fibre reinforced earth dam," no. March, 2020, doi: 10.13140/RG.2.2.34924.10887.

[5] N. A. Vodounon, C. Kanali, J. Mwero, and M. O. A. Djima, "Splitting Tensile Strength, Physical and Durability Properties of Cement Stabilized Earth Block Reinforced with Treated and Untreated Pineapple Leaf Fibre," vol. 8, no. 2, pp. 49-57, 2019, doi: 10.5539/jmsr.v8n2p49.

[6] Universiti Teknologi MARA., IEEE Malaysia Section., M. IEEE Conference on Open Systems: 2010 : Kuala Lumpur, M. International Conference on Computer Application and Industrial Electronics: 2010: Kuala Lumpur, and M. International Conference on Science and Social Research: 2010 : Kuala Lumpur, “2010 Icos, Iccaie, Cssr,” no. Cssr, pp. 1011-1016, 2010.

[7] N. A. Vodounon, "Analysis of engineering properties of laterite bricks reinforced with pineapple leaf fibres," no. September, 2018.

[8] E. R. Andal and J. B. P. Juanzon, "Identifying risks in implementing sustainable building materials in condominium fit-out projects using analytic hierarchy 
process," Civil Engineering and Architecture, vol. 8, no. 6, pp. 1266-1276, 2020, doi: 10.13189/cea.2020.080610.

[9] R. K. Dutta and V. Gayathri, "Effect of addition of treated coir fibres on the compression behaviour of clay," Jordan J. Civ. Eng., vol. 6, no. 4, pp. 476-488, 2012.

[10] S. Dixit, R. Goel, A. Dubey, P. R. Shivhare, and T. Bhalavi, "Natural fibre reinforced polymer composite materials - A review," Polym. from Renew. Resour., vol. 8, no. 2, pp. 7178, 2017, doi: 10.1177/204124791700800203.

[11] J. Menon and M. S. Ravikumar, "Evaluation of Laterite Soil Stabilized using Polymer Sack Fibers," no. 6, pp. 682-685, 2019.

[12] T. S. K. Kumar, R. P. Ponnala, and S. Ravi, "Behavior of Natural Fiber-Polymer Composites using Compression Moulding Process," vol. 7, no. 12, pp. 175-177, 2018.

[13] N. H. H. Abdullah, N. H. A. Aziz, F. F. Jaafar, N. M. Osman, A. Ahmad, and S. A. Hamid, "Effect of different fibre reinforcement type to the shear strength of soft soil at varying moisture condition," J. Phys. Conf. Ser., vol. 1349 , no. 1, 2019, doi: 10.1088/1742-6596/1349/1/012126.

[14] C. Han, Y. He, J. Tian, J. Zhang, J. Li, and S. Wang, "Shear strength of polypropylene fibre reinforced clay," Road Mater. Pavement Des., vol. 0, no. 0, pp. 1-18, 2020, doi: 10.1080/14680629.2020.1798807.

[15] F. Jalaei and A. Jrade, "Effect of Polypropylene Fiber Length on the Flexural and Compressive Strength of Compressed Stabilized Earth Blocks," Constr. Res. Congr. 2014, no. 2008, pp. 140-149, 2014.

[16] S. Selsiadevi and E. Ramani Sujatha, "Physical, Mechanical and Durability Properties of Soil Building Blocks Reinforced with Synthetic Fibre," Int. J. Eng. Technol., vol. 7, no. 3.12, p. 201, 2018, doi: 10.14419/ijet.v7i3.12.16024.

[17] J. Menon, "Strength evaluation of laterite soil stabilized using polymer fibers," vol. 9, no. 2, pp. 227-234, 2018.

[18] M. M. Rao, "Effect of Aspect Ratio of Fiber in HDPE Reinforced Concrete," vol. 8, no. 09, pp. 164-171, 2019.

[19] M. R. GS Sudhikumar, KB Prakash, "Effect of aspect ratio of fibers on the strength characteristics of slurry infiltrated fibrous ferrocement," vol. 3, no. 2, pp. 29-37, 2014.

[20] A. Amadi, "Evaluation of Coefficient of Permeability on Lateritic Soil Contaminated with Organic Chemicals," no. December 2015, 2019.

[21] A. Fajobi, F. Falade, A. Adepelumi, and O. Akindulureni, "Evaluation of hydraulic conductivity of lateritic soils using integrated approach: southwestern Nigeria case study," Int. $J$. Adv. Geosci., vol. 3, no. 1, p. 1, 2014, doi: 10.14419/ijag.v3i1.3552.

[22] O. Ogunsanwo, "Some geotechnical properties of two laterite soils compacted at different energies," Eng. Geol., vol. 26, no. 3, pp. 261-269, 1989, doi: 10.1016/0013-7952(89)90013-6.
[23] R. A. García-Gaines and S. Frankenstein, "USCS and the USDA Soil Classification System, ERDC/CRREL TR-15-4," no. March, p. 37, 2015, [Online]. Available: https://apps.dtic.mil/dtic/tr/fulltext/u2/a614144.pdf.

[24] H. C. D. F. J. Martin, "Laterite and lateritic soils in Sierra Leone," 1923.

[25] F. Achampong, R. A. Anum, P. F. Boadu, N. B. Djangmah, and L. P. Chegbele, "Chemical Stabilization of Laterite Soils for Road construction," vol. 4, no. 11, pp. 2019-2041, 2019.

[26] S. K. Patel and B. Singh, "Unconfined Compressive Strength Behaviour of Fibre-Reinforced Lateritic Soil," vol. 1, no. 4, pp. 93-98, 2014.

[27] I. Testad, A. Corbett, and D. et al Aarsland, "ORE Open Research Exeter," J. Clean. Prod., 2013.

[28] M. A. Al-Neami, F. H. Rahil, and Y. H. Al-Ani, "Behavior of Cohesive Soil Reinforced by Polypropylene Fiber," Eng. Technol. J., vol. 38, no. 6A, pp. 801-812, 2020, doi: 10.30684/etj.v38i6a.109.

[29] A. Abou Diab, S. S. Najjar, S. Sadek, H. Taha, H. Jaffal, and M. Alahmad, "Effect of compaction method on the undrained strength of fiber-reinforced clay," Soils Found., vol. 58, no. 2, pp. 462-480, 2018, doi: 10.1016/j.sandf.2018.02.013.

[30] T. N. Dave, D. Patel, G. Saiyad, and N. Patolia, "Use of Polypropylene Fibres for Cohesive Soil Stabilization," no. August, pp. 409-417, 2020, doi: 10.1007/978-981-15-0890 $-5 \_34$.

[31] R. Marçal, P. C. Lodi, N. de S. Correia, H. L. Giacheti, R. A. Rodrigues, and J. S. McCartney, "Reinforcing effect of polypropylene waste strips on compacted lateritic soils," Sustain., vol. 12, no. 22, pp. 1-16, 2020, doi: $10.3390 /$ su12229572.

[32] A. S. Zaimoglu and T. Yetimoglu, "Strength Behavior of Fine Grained Soil Reinforced with Randomly Distributed Polypropylene Fibers," Geotech. Geol. Eng., vol. 30, no. 1, pp. 197-203, 2012, doi: 10.1007/s10706-011-9462-5.

[33] S. Patil, H. M. Somasekharaiah, H. S. Rao, and V. G. Ghorpade, "Behaviour of fly ash and metakaolin based composite fiber (Glass and polypropylene) reinforced high performance concrete under acid attack," Civil Engineering and Architecture, vol. 9, no. 4, pp. 1026-1047, 2021, doi: 10.13189/cea.2021.090406

[34] M. Malekzadeh and H. Bilsel, "Hydro-mechanical behavior of polypropylene fiber reinforced expansive soils," KSCE J. Civ. Eng., vol. 18, no. 7, pp. 2028-2033, 2014, doi: 10.1007/s12205-014-0389-2.

[35] N. Ali et al., "Compressive strength and initial water absorption rate for cement brick containing high-density polyethylene (HDPE) as a substitutional material for sand," IOP Conf. Ser. Mater. Sci. Eng., vol. 271, no. 1, 2017, doi: 10.1088/1757-899X/271/1/012083. 